\title{
Coal Fuel Efficiency with Mixed Palm Shell Biomass for Steam Power Plant
}

\author{
Hamzah Eteruddin \\ Dept. of Electrical Engineering, \\ Faculty of Engineering \\ Universitas Lancang Kuning \\ (UNILAK), \\ Jl. Yos Sudarso, km 8 Rumbai, \\ 28265 Rumbai, Riau, Indonesia \\ hamzah@unilak.ac.id \\ Zulfahri \\ Dept. of Electrical Engineering, \\ Faculty of Engineering \\ Universitas Lancang Kuning \\ (UNILAK), \\ Jl. Yos Sudarso, km 8 Rumbai, \\ 28265 Rumbai, Riau, Indonesia \\ zulfahri@unilak.ac.id
}

\author{
Muhammad Ridwan \\ Dept. of Electrical Engineering, \\ Faculty of Engineering \\ Universitas Lancang Kuning \\ (UNILAK), \\ Jl. Yos Sudarso, km 8 Rumbai, \\ 28265 Rumbai, Riau, Indonesia \\ ridwan.ftunilak05@gmail.com
}

Yanuar Z. Arief

Dept. of Electrical and Electronic Eng., Faculty of Engineering Universiti Malaysia Sarawak (UNIMAS)

Kota Samarahan, Sarawak, Malaysia ayzulardiansyah@unimas.my

\author{
Monice \\ Dept. of Electrical Engineering, \\ Faculty of Engineering \\ Universitas Lancang Kuning \\ (UNILAK), \\ Jl. Yos Sudarso, km 8 Rumbai, \\ 28265 Rumbai, Riau, Indonesia \\ monice@unilak.ac.id \\ Fathimah Hasanti \\ Dept. of Computer Network \& \\ Security, \\ Faculty of Engineering \\ Universiti Teknologi Malaysia (UTM) \\ Skudai, Johor Bahru, Malaysia \\ fathasanti@gmail.com
}

\begin{abstract}
The accumulation of coal-based fuels is depleting and to obtain coal fuel requires a great amount of money, as a corollary, measures must be taken to reduce the usage of this fuel. PT. Pembangkit Jawa Bali (PJB) is currently investigating the co-firing technique by using oil palm shell biomass waste as a combination coal fuel with a proportion of $95 \%$ coal and $5 \%$ palm shell, the efficiency results will be compared to $100 \%$ of coal fuel. In this research, the Mathcad program and the Professional Simulator 8 were employed, the specific fuel consumption (SFC) technique is used to determine the efficiency of production expenses, as well as the direct and indirect methods to calculate the boiler efficiency. The results reveal that 4.09 IDR/ $\mathrm{kWh}$ reduction in primary energy expenses could be achieved $(0.65 \%)$. Co-firing fuel will undoubtedly have a significant impact on the boiler's performance, therefore when using $100 \%$ of coal as a fuel, the boiler efficiency value is $63.38 \%$ (Direct Method), while using the Indirect Method will produce up to $82.24 \%$, respectively. However, when using co-firing fuel with $95 \%$ of coal and $5 \%$ of palm shell (Direct Method), the boiler efficiency value is $63.92 \%$, and $83.71 \%$ when using the Indirect Method.
\end{abstract}

Keywords - Co-firing method, production cost efficiency, palm shell, biomass, boiler efficiency, direct method, indirect method

\section{INTRODUCTION}

Electric power generation, both new renewable energy and fossil energy generation, has been widely investigated [1]-[6]. A boiler in a Steam Power Plant (SPP) is a facility that transforms liquid water to steam. Boilers use Circulating Fluidized Bed Combustion (CFBC) as one of its technologies [7-10]. The system has several advantages of working principles such as a compact boiler design, fuel flexibility, high combustion efficiency and low emission of harmful pollutants such as Sulfur Oxide (SOx) and Nitrogen Oxide (NOx) [7]. Coal is the primary fuel, however biomass such as palm shells, sawdust, or other agricultural waste can also be used in boilers only if it mixed. [11-13].

The SPP Tenayan power station in Riau province, Indonesia has a capacity of $2 \times 110 \mathrm{MW}$ and it is one of the PLN power plants run by PT. PJB that utilizes low calories or Low Rank Coal (LRC) with a heating value of 3,800-4,700
$\mathrm{kCal} / \mathrm{kWh}$ as a fuel [14], [15]. LRC has a high sulfur concentration, which is bad for equipment, particularly the tube Boiler. SPP Tenayan uses a Circulating Fluidized Bed (CFB) boiler, which has a wide range of fuel options, high combustion efficiency, effective sulfur absorption, low NOx emissions, and a lower furnace cross section. [16], [17]

Riau Province is home to a palm oil plant with a capacity of 12,170 tons per hour [18]. The potential for Palm Kernel Shell (PKS) or biomass waste is very substantial in terms of shifting away from reliance on fossil fuels and toward green power plants. Increasing the Medium-Rank Coal (MRC) ratio, contributed to higher furnace bed and intake cyclone temperatures [15], [19]. Meanwhile, the implementation of CFB at the SPP Tenayan supports co-firing experiments using palm shell biomass. This study discusses the comparison of the fuel efficiency of pure coal and coal with a mixture of PKS biomass in Boiler Unit 2 at PT. PJB Tenayan Raya using specific fuel consumption technique (SFC).

\section{METHOD}

The Specific Fuel Consumption (SFC) can be used to determine an-engine's economic value [20], [21]. SPLN No. 80 (1989) says, this parameter can be used to compute the amount of fuel required to create a specified amount of power in a given time interval. The following are some of the formulas that are used to calculate the particular fuel consumption [22]:

a) Specific Fuel Consumption Brutto (SFCB)

$$
S F C=\frac{3.6 \times 10^{6} m_{f}}{P_{e f f}}=\frac{10^{3}}{(\mathrm{~h} \mathrm{LHV})} \mathrm{g} / \mathrm{kWh}
$$

Where $\mathrm{m}_{\mathrm{f}}$ is the fuel consumption in $\mathrm{kg} / \mathrm{s}, \mathrm{P}_{\text {eff }}$ is power (brake) effective machine, the efficiency $(\eta)$ of the engine, and LHV which is the lower calorific value fuel in $\mathrm{kWh} / \mathrm{kg}$, SFC gross $=\mathrm{Qf} /(\mathrm{kWh}($ gross $))$.

b) Specific Fuel Consumption Netto (SFCN)

$\mathrm{SFC}$ netto $=\mathrm{Qf} /(\mathrm{kWh}($ netto $))$ 